\title{
Professionalism and professional education in the context of sustainable development
}

\author{
Olga Anikeeva, Valeriya Sizikova, Anastasia Karpunina, and Olga Afanasyeva* \\ Russian State Social University, Vilhelm Pick Str., 4, corp. 1, 129226 Moscow, Russia
}

\begin{abstract}
The sustainable development serves as the resulting index of new economic, social and political development in society with multiple uncertain parameters due to the increased process dynamics. It foresees the creation of personnel training system, the personnel able to develop proactively and fit the times. Consequently, it sets other tasks to the professional education system. The analysis conducted by the authors is directed to studying the term "professionalism" on the example of the social sphere, the dynamics of key professional functions and possibilities of social sphere specialists' professional conversion. Respectively, primary trends in the social education development and the compliance with the labour market needs in social sphere, the impact of professional activity of social sphere specialists towards sustainable development in our country were analysed. The evaluation of study results was carried out during the development of professional and education standards, their professional and public hearings, and the development of recommendation on application of network and distance technologies in the social education.
\end{abstract}

\section{Introduction}

The strong interest to the sustainable development concept that burst out at the close of XX century - in the early XXi century, has slightly blunted over the subsequent years. However, the concept applicability remains. The interest to it translates into practices.

In order to support the sustainable development, the personnel training concept shall be revised. New requirements to training of professionals include rather conflicting conditions: sound theoretical training, focus on practice and applied competence formation, flexibility, mobility, creativity and teamwork skills, ability to make decisions independently and bear the individual responsibility for them. Provided that it should have been made within the minimum period of time and cheaply, if possible. What the XXI century professional education would be?

The profession anthropology and psychology has been studied since the middle of XIX century, E. Durkheim connected them with the differentiation of labour and the solidarity analysis. P.A. Sorokin noted the somatic deformation that affects professionals [1]. J. Habermas considered professions through the lens of personal self-fulfilment. The professionalization of activities related to relations of power and realization of different modern society social institutes' functions shall add the social load and social value to the

\footnotetext{
* Corresponding author: olga-double@mail.ru
} 
professional education and impacts the conflict intensity in society [2]. This is the professional education model of industrial and post-industrial society that has been implemented over the XX century.

The new professionalism insight in the information society is connected with the fact that stable boundaries transcend. Professions become dynamic, interlace and interrelate, allied and combined professions emerge. The more dynamic the professional is striving to fit the times, more actively he or she will gain new and required for his/he activity competences and will be more successful [3]. Finally, the blurring of term "profession" has led some scientists to conclusion that the profession as the certain type of activity disappears. Provided that it is not about disappearing of certain professions due to their conventionalism. It is rather the conclusion about the fact that some professional training and further the stable appearance of activity will be a thing of the past giving the place to specialists with diversified training for the unconventional activities, who able to satisfy the society need in new hyperdynamic conditions. These are the trends of modern professionalism evolution.

There are too many studies in this problem space (challenges of new professional education bother many scientists) and too little at the same time, as new approaches in this sphere are to the greatest extent connected with civilizational challenges, the social sphere status, development issues and the new man and the society personality becoming. In the context of educational issues some of the above-mentioned challenges have not resolved since the previous stage. Not only in Russia, but in other developed countries, the higher education is sometimes inaccessible to whole social strata; educational technologies in a massive way lag far behind the state-of-the art information technologies and pedagogic objectives do not correspond educational and teasing objectives [4, 142-145]. Many countries are concerned about material and social expenses on the professional education, the allocation of liability for the personnel training results between the society social institutes, the state and the business as the core employers; and the issue of educational to pedagogic tasks ratio in the modern personnel training.

\section{Materials and Methods}

The research conducted by the authors is directed to studying the term "professionalism" on the example of the social sphere (more particularly, in the social protection and service system); the detection of the most sought-after professional functions in social work professions; studying the social work impact on the society stabilization and the sustainable development and the establishment of professional education fundamentals in specialization "Social Work".

The study was carried out in three stages: in 2013 (the grant of Ministry of Labour and Social Protection of the Russian Federation on the Development of Social Work Specialist Professional Code of Conduct); in 2015-2019 (within the tailoring of Social Work Specialist Professional Code of Conduct and Federal State Educational Standards of Higher and Vocational Professional Education); in 2020 (within the analysis of labour market needs due to innovative technologies of social work).

Research methods included comparative and post-event analysis, the structural and functional approach, the method of professional activity modelling, the method of design (professional and educational standards). The applied methods included the analysis of official documents and statistical data, the polling $(2013-\mathrm{N}=1158 ; 2015-\mathrm{N}=254$; random quota sample), the focus group method $(\mathrm{N}=37)$, the export poll $(\mathrm{N}=257)$. The study was supplemented by the in-depth interview method $(\mathrm{N}=24)$ of social service organizations' directors, social work specialists, representatives of municipal government authorities on the issues of professionalism modern understanding and the labour market requirements to social 
work specialists, the impact of professional social work on the social stability and the society sustainable development.

\section{Results and Discussion}

The study of professionalism concept, fundamentals of specialist professional activities and social education specifically via the example of social work is attributable to the fact that this profession directly impacts the population well-being and provides the basis for the sustainable development. According to the UN documents, the sustainable development indicators are divided into 4 groups; the first group is only social. And it is correctly so, as without the reliable social basis the economic progress and the society stable development are impossible [5, 64-81]. The same conclusion comes from the global definition of social work "The social work profession promotes social change, problem solving in human relationships and the empowerment and liberation of people to enhance well-being". [6].

In Russia the "social work" profession is implemented at three levels: the social worker himself/herself (mainly, is engaged in home servicing, could not have the higher education); social work specialist (has higher of vocational professional education, provides qualified community social relief, coordinates the activity of various specialists and organizations involved in social protection and relief); and director of social service organizations. All three professional groups were respondents.

The study of key, the most sought-after functions of social work specialists discovered differences: in 2013 the most sought-after functions were diagnostic and social and technological functions ( $88 \%$ and $77.75 \%$ respondents) and the least were social and design and research functions (54.3\% and 52.1\%) [7]. By 2020 the situation has changed, the role of creative technologies has grown and the expert poll of social service organizations' directors showed that they started to rate teamwork and individual decision-making abilities higher $(67.7 \%)$. It simultaneously evidenced the increase of social service organizations' director activity.

The analysis of the most sought-after social work functions' dynamics has shown that over the last 10 years the professional activity concepts had shifted: if earlier (in 1991-2000) the main objective was the immediate social relief to population in distress, then in recent years technologies of social prevention aimed to the stabilization of social situation and the sustainable development came in. Social work professionals master forecasting and design functions, progressively referring to the conducted studies, including the monitoring mode. Such conclusions are confirmed during focus-group studies that involved specialists, directors and employees.

On the basis of conducted study, the professional codes of conduct of social worker, social work specialist and social service organization director were developed. Such codes were represented by the model of professional activity combining conventional and innovative technologies of social work, the competence formation designed to only for actual moment, but also for the future. They were approved Ministry of Labour and Social Protection of the Russian Federation in 2013. In 2015-2019 the same working group conducted the tailoring of three professional codes and in 2020 they were approved. The special task of development team composed of the scientific and methodological support of professional code of conduct implementation in the population social service practice.

This experience was considered in developing the Federal State Educational Standards of Higher and Vocational Professional Education. Its keystone became the establishment of consistency between these educational standards and mainly the formation of professional competences depending the employee needs. With the content and in form, the educational process is close to the solution of practical tasks and focused on the most sought-after professional functions. Educational standards considered the model of future specialist, who 
able accomplish certain professional functions now and intensively learn in the future replenishing its professional stock.

However, it should be remembered that obtained knowledge and competences are still generalized. The expert poll of social service organizations' directors showed that the frustration about graduates' handling competence remains $(68,5 \%)$. The analysis of foreign experience showed that the additional training of graduates for performing certain professional duties at workplace is the common practice for all countries and is funded by employers. On this stage the lack of practical experience is compensated and further the professional experience will be replenished by the continuing professional education system. The Ministry of Labour and Social Protection of the Russian Federation launched an initiative to allocate funding to employers hiring graduates (of higher education institutions and colleges) in order to provide graduates the possibility to complete professional internship and obtain the initial practical professional experience. It means the allocation of one living minimum wage within first 3 months of young specialist's employment and another one within next 3 months. It is foreseen that such measures can facilitate securing of work places by young specialists and increase their adjustment to the labour market requirements.

Thus, the professional activity along with the professional social education are changing: the content modifies, new professional and education technologies are developed. 2020 events with the COVID-19 pandemic resulted in the necessity to transform the educational process into the distance format. Scientists jumped into studying of such novation. Conclusion appeared to be contradictory. According to authors, over $78 \%$ of lecturers highly appreciated the online learning possibilities, its flexibility, possibility to involve major scientists and practicians in teaching, providing students the possibility to choose the academic format and load, in-depth study of various subjects or separate disciplines. However, attempts of professional education system managers to bring all educational forms to online learning met an active resistance: the vast majority of students $(89.7 \%)$ and lecturers (98.4\%) expressed the opinion that distance forms are only auxiliary educational form and the personal contact shall remain the key form. Only the person-to-person interaction forms the ability to think and interpret the obtained actual material and knowledge, express own position and maintain it, the ability to communicate with public. Only in personal contact the lecturer can actually evaluate the level of perception and understanding of material. Finally, during the quarantine the pedagogic work of higher educational institutions and colleges was highly appreciated; the involvement in socially beneficial activities, volunteering, student self-governance. The experience suggests that students which mastered Soft Skill competences better adjust in the profession, pursue a career, develop innovative technologies, they are pointed to creative profession absorption.

The conducted study resulted in the conclusion that in recent years the professionalism understanding by both employers and youngsters obtaining the professional education has changed. The most typical wording can be considered the following definition of employers: "The professionalism is an ability of employee to perform all required professional functions, find the right solution in hardship and help citizens in need". In such wordings prevail high estimated executive qualities of employees. The professionalism for students is the high level of learning, including the state-of-the art methods and technologies of work; the ability of creative application, find new and more effective solutions of professional tasks. Further young people noted such professionalism side as professional self-consistency and possible self-realization.

The correlation of such poll results shows that in social sphere on the part of employers still prevail requests for executive qualities and on the part of young people - the creative attitude to profession. The important difference is reflected in the work of the most advanced lecturers of higher and vocational professional education. Their pedagogic technologies 
foresee the inclusion of practice-oriented creative tasks to the educational process such as social design, competitive tasks, disputing methods.

The study conducted by authors had foreseen the analysis of concepts in both Russian and foreign scientific literature. The appeal to the challenge background showed that the number of works highlighted the essential feature of industrial era professional education: somatic accentuation and emotional burnout. This feature was predetermined by the repetition of professional actions, the stable ser of professional knowledge and skills repeated over the years; the certain type of physical actions and communication method [1].

In new conditions the significance of social work in the context of sustainable development is emphasised by J. Evetts [8] and M. Payn [9]. New society demands point the attention to self-realization in profession and self-reliance. Such side of the professional training, especially in the social work, is emphasised by Robert Weinbach [10]. The professionalism understood as the attitude to employee social upward mobility is highlighted in works of Saks [11], Palattiyil, Pawar [12], et al. To some extent such approaches are solidarized by J. Henslin, who insists on alignment of initial student possibilities that is appropriate to strategical approaches to solution of social issues in several foreign countries [13].

However, the positions of authors are far from unanimity: R. Hugman thinks that the social works does not require the professionalism at all, it only need special personal qualities: empathy and ability to mercy [14]. The comparative analysis of approaches to professionalisation of social work in Russia and abroad conducted by O. Shalkovskaya [15] assists in the formation of new models of professionals in social sphere.

The development perspectives of social education and professionalisation of social work became the core subject of scientific works of the following authors: [16]. Russian authors note the significance of scientific and fundamental training of social work specialists: T.N. Yudina states that only the deep theoretical basis can provide the ground for professional competence expansion, for correct self-determination of the route that can assist the graduate to achieve the real professionalism [17]. It especially relates to the professional education and social service organization director's personality formation [18]. The similar opinion is maintained by A. Egorychev and L. Mardahaev et al. [19;20]. The individualisation of professional training is considered in works of S.N. Fomina [21].

The analysis of scientific works and applied studies devoted to professionalization and professional education in general, and in particular to social education, shows that the conclusion on social work significance for modern world and sustainable development is highly estimated.

\section{Conclusion}

The modern labour market dynamics set new tasks to professional education that qualitatively differ from the previous stage tasks. These tasks are topical for social sphere specialists, especially for social protection and social service specialists, because the goal of their professional activity is the creation of social basis for the society sustainable development.

The study conducted by authors showed that the social work professionalization proceeds within the general context of professional activity and education sphere changes. The comparison of results obtained at the different study stages showed that the social work as the type of activity shifts to a new model: from social emergency aid and rescue of population in distress to the prevention of social ill-being. Such shift requires new personnel and forms of social education on both higher and vocational professional education levels. New conditions foresee deep theoretical training, practice-oriented, applied training, the application of new educational technologies, stake on individualization of educational routes, enhanced information support of educational process. The specialist of new era is self- 
consistent, proactive, creative person, who is ready for constant professional improvement, able to self-reflection, conscious choice of own professional advancement directions.

However, the study reveals latent contradictions: the labour market, the management system in social sphere, social service and protection system remain rather conservative. The management is not ready for novations required in the context of sustainable development.

The study allowed to develop the model of social worker, social work specialist and social service organization director professional activities that provides ways for overcoming such contradictions. Professional codes of conduct conversely became the basis for development of education standards of higher and vocational professional education levels.

The implementation of new professional and education standards, training of new social work specialists will positively contribute to the society social stability, Russian citizen wellbeing improvement and thus creates conditions for the society sustainable development.

\section{References}

1. P.A. Sorokin, Profession impact on people behaviour and reflexology of professional groups, 334 (19994)

2. T.B. Schepanskaya, Journal of Sociology and Social Anthropology, 6(1) (2003)

3. P. Romanov, E. Yarskaya-Smirnova, Journal of Social Policy Studies, 234 (2015)

4. L.I. Starovoytova, Professionalism and creativity in social work. Collection of scientific articles, 142 (2017)

5. P. Romanov, E. Yarskaya-Smirnova, Anthropology of professions or Admittance allowed, 64 (2011)

6. International Federation of Social Workers (IFSW). International definition of social work, www.ifsw.org/

7. V.V. Sizikova, O.A. Anikeeva, Ya.V. Shimanovsakaya, O.O. Kopnina, Indian Journal of Science and Technology, 9(42) (2016)

8. Robert W. Weinbach, The social worker as manager. A practical guide to success. Fourth edition, 356 (2003)

9. M. Payne, International Social Work. Essex: University of Essex, 41(4), 443 (1998)

10. J. Evetts, International Sociology, 18(2) (2003)

11. M. Saks, Social Work in the UK: a Changing Profession under Challenge in Turbulent Times. Paper presented in Sessions of the Research Network on Sociology of Professions (RN 19) at the 10th Conference of the European Sociological Association, Geneva, Switzerland (2011)

12. G. Palattiyil, M. Pawar, D. Sidhva, J.C. Anand, J. Cox, P.K. Shaiahan, Reclaiming international social work in the context of the Global Agenda for Social Work and Social Development: Some critical reflections. International Social Work (2018)

13. R. Hugman, Social Work and De-Professionalisation. The Sociology of the Caring Professions, 178 (2003)

14. Henslin Jamcy M., Essentials of sociology. A down-to-earth approach. Southern Illinois University, 7, 488 (2004)

15. O. Shalkovskaya, The journal of social policy studies, 14(2), 245 (2016)

16. Anthropology of professions: Employment limits in instability era, Library of The Journal of Social Policy Studies, 236 (2012)

17. T.N. Yudina, Materials of Ivanov Scientific Conference, 4, 290 (2015) 
18. A.M. Egorychev, L.V. Mardahaev, A.I. Rybakova, S.N. Fomina, V.V. Sizikova, Journal of Advanced Research in Law and Economics, 5(2), 82 (2014)

19. A.M. Egorychev, A.G. Akhtian, A.S. Seitbattalova, Yu.V. Chelysheva, I.D. Levina, Man in India, 97(16), 199 (2017)

20. S.N. Fomina, N.A. Bereza, A.A. Kvitkovskaya, Transactions of Russian State Social University, 17, 3(148), 42 (2018)

21. V.V. Sizikova, O.A. Anikeeva, Ya.V. Shimanovsakaya, S.N. Kozlovskaya, A.G. Akhtyan, E.A. Vorontsova, AD ALTA Journal of interdisciplinary research , 9, 1(6), 51 (2019) 